\title{
Fighting against hematological malignancy in China: from unique system to global impact
}

\author{
LV Meng ${ }^{1,2} \&$ HUANG XiaoJun ${ }^{1,2 *}$ \\ ${ }^{1}$ Peking University People's Hospital, Peking University Institute of Hematology, Beijing Key Laboratory of Hematopoietic Stem Cell \\ Transplantation, Beijing 100044, China; \\ ${ }^{2}$ Peking-Tsinghua Center for Life Sciences, Beijing 100087, China
}

Received July 31, 2015; accepted August 16, 2015; published online November 13, 2015

\begin{abstract}
During recent decades, substantial progress has been made in clinical strategies for treating hematological malignancies. Not only did China benefit from the global progression in the management of acute promyelocytic leukemia, risk-stratification-directed strategies for acute or chronic leukemia and haploidentical hematopoietic stem cell transplantation, the unique system developed by Chinese doctors has also become inspiration for refining global clinical practice. The multicenter trials and collaborations adhering to international standards might further strengthen the global impact and lead the way in specific fields of research worldwide.
\end{abstract}

hematological malignancy, acute promyelocytic leukemia, acute myeloid leukemia, chronic myeloid leukemia, haploidentical hematopoietic stem cell transplantation

Citation: Lv M, Huang XJ. Fighting against hematological malignancy in China: from unique system to global impact. Sci China Life Sci, 2015, 58: 1183-1190, doi: 10.1007/s11427-015-4926-0

Hematological malignancies, including acute and chronic leukemia, lymphoma and multiple myeloma, constitute a series of critical life-threatening diseases, especially in children and adolescents [1]. During recent decades, substantial progress has been made in clinical strategies for treating hematological malignancies, which have shifted from "incurable" to "curable". In general, the 3- to 6-year disease-free survival (DFS) of hematological malignancies in comprehensive hematology centers in China reached $60 \%-70 \%$, and in several diseases the 2-year DFS exceeded 95\% [2-8]. In this process, Chinese patients benefited from the global developments of hematological malignancy therapy, not only with respect to therapeutic strategies but also with regard to the methodology in clinical trial design, standardization of clinical practice and multi-center cooperation. The innovations of Chinese doctors also prompted

*Corresponding author (email: huangxiaojun@bjmu.edu.cn) global progression, especially in managing acute promyelocytic leukemia (APL), risk-stratification-directed strategies for leukemia and haploidentical hematopoietic stem cell transplantation (Haplo-HSCT). The present review focuses on the unique anti-malignancy clinical strategies innovated by Chinese doctors and provides insight into their global impact.

\section{Acute promyelocytic leukemia (APL)}

In the "chemotherapy era" with daunorubicin or earlier, APL was once a highly fatal malignancy because of a high incidence (approximately 30\%) of early death caused by hemorrhage and so on, while the first complete remission rate (CR1) was less than 50\% [9-11]. Chinese doctors had made special contributions by introducing targeted therapy including all-trans retinoic acid (ATRA) and arsenic acid 
for APL [12]. In the late 1980s, the Shanghai group [13,14] first introduced ATRA into the clinics, and the CR1 rate reached $90 \%$ without increasing the risk of hemorrhage. These findings of ATRA were soon replicated in France and the USA, which advocated the application of ATRA in both induction and maintenance compared with the standard chemotherapy using daunorubicin and cytarabine $[15,16]$. Because the therapeutic effects of ATRA were limited due to the high relapse rate in maintenance [17], the introduction of arsenic acid from traditional Chinese medicine (in the form of arsenic trioxide or arsenic disulfide) by Harbin, Shanghai and Beijing further improved the clinical outcomes of APL, yielding the 3- to 6-year DFS of about 80\%-90\% [18-20]. Although arsenic trioxide (ATO) was discovered more than a decade before the discovery to ATRA, this unique system was underestimated or ignored outside of China until a series of clinical reports and mechanism studies were conducted at the molecular level according to international standards [21-24]. Subsequently, ATRA plus ATO were gradually accepted as the first-line treatment over chemotherapy in the management of APL [25-28].

Therefore, modern biomedical approaches and welldesigned clinical trials play key roles in connecting the unique systems of China with those of the world. Realgar-Indigo naturalis formula (RIF) for APL is another concrete example. The formula is representative of traditional Chinese medicine, prescribing a combination of plant species and minerals based on clinical experience. Although the clinical efficacy of RIF has been proven in a single-arm clinical trial in the 1990s [29], the international hematology community did not recognize the benefits of RIF because of the obscure mechanisms and the absence of strict trials. By dissecting the mode of action of RIF at the molecular, cellular, and organism levels, the Shanghai group [30] reported tetra-arsenic tetrasulfide as a principal component of RIF, whereas other adjuvant ingredients yielded synergy in targeting APL cells in vitro and in vivo. Recently, a prospective, multi-center, randomized, controlled study led by the Shanghai and Beijing groups proved that oral RIF achieved a high rate of remission and survival comparable with that of intravenous ATO as a front-line treatment for newly diagnosed APL, the 3-year overall survival rate (OS) was 99.1\% (RIF) and 96.6\% (ATO) (Table 1) [5]. Later, in a single-arm study of non-high-risk patients by the Beijing group [31,32], oral RIF and ATRA were administered to patients in a largely home-based treatment protocol, promoting the new era to "Cure leukemia in out-patient department".

Despite the high incidence of CR and OS, resistance to arsenic acid resulted in a worse outcome. Amino acid substitutions of A216V and L218P in the promyelocytic leukemia protein (PML) B2 domain have been detected in patients clinically resistant to arsenic trioxide [33], recently the Beijing group identified 4 new mutations in PML transcripts with A216T, S214L, L217F, and S220G, which suggested the presence of a PML mutational hot-spot domain (C212-S220). These mutations may be helpful in guiding risk-stratification-directed treatment choices in the

Table 1 Recent multi-center studies on hematologic malignancies in China ${ }^{\text {a) }}$

\begin{tabular}{|c|c|c|c|c|c|c|c|}
\hline Disease & Treatment & Design & $\begin{array}{c}\text { Centers } \\
(\mathrm{n})\end{array}$ & $\begin{array}{l}\text { Patients } \\
(\mathrm{n})\end{array}$ & Main Results & Conclusions & Publication \\
\hline $\begin{array}{l}\text { AML } \\
\text { CR1 }\end{array}$ & $\begin{array}{l}\text { HID vs. ISD } \\
\text { allo-HSCT }\end{array}$ & $\begin{array}{c}\text { Donor } \\
\text { availability }\end{array}$ & 3 & 450 & $\begin{array}{l}\text { 3-year DFS:HID (74\%) and ISD } \\
(78 \%)(P=0.34) \\
\text { 3-year OS: HID }(79 \%) \text { and ISD } \\
(82 \%)(P=0.36)\end{array}$ & $\begin{array}{c}\text { HID achieves similar out- } \\
\text { comes to ISD HSCT for AML } \\
\text { CR1 }\end{array}$ & Wang et al. [3] \\
\hline AML & $\begin{array}{l}\text { HAA vs. HAD } \\
\text { vs. DA }\end{array}$ & RCT & 17 & 620 & $\begin{array}{c}\text { CR: HAA }(71 \%) \text { vs. HAD }(67 \%) \text { vs. } \\
\text { DA }(61 \%) \\
\text { 3-year EFS: } \\
\text { HAA }(35.4 \%) \text { vs. HAD }(32.7 \%) \text { vs. } \\
\text { DA }(23.1 \%)\end{array}$ & $\begin{array}{l}\text { HAA is a treatment option for } \\
\text { young, newly diagnosed pa- } \\
\text { tients with AML }\end{array}$ & Jin et al. [45] \\
\hline $\begin{array}{l}\mathrm{t}(8 ; 21) \\
\mathrm{AML}\end{array}$ & $\begin{array}{l}\text { Chemo vs. } \\
\text { Allo-HSCT }\end{array}$ & $\begin{array}{l}\text { Risk di- } \\
\text { rected }\end{array}$ & 3 & 137 & $\begin{array}{c}\text { High-risk CIR: } \\
\text { HSCT }(22.1 \%) \text { vs. Chemo }(78.9 \%) \\
\text { 5-year DFS }(61.7 \%) \text { vs. Chemo } \\
(19.6 \%)\end{array}$ & $\begin{array}{l}\text { MRD-directed pre-transplant } \\
\text { risk stratification may im- } \\
\text { prove the outcome of } \mathrm{t}(8 ; 21) \\
\text { AML in CR1 }\end{array}$ & Zhu et al. [49] \\
\hline $\begin{array}{l}\mathrm{t}(8 ; 21) \\
\text { AML }\end{array}$ & Allo-HSCT & $\begin{array}{l}\text { Risk di- } \\
\text { rected }\end{array}$ & 4 & 92 & $\begin{array}{l}\text { Multivariate: MMR in first } 3 \text { months } \\
\text { CIR: HR } 0.07(0.02-0.26) \\
(P=0.001) \\
\text { LFS: HR } 0.13(0.05-0.34) \\
(P=0.001) .\end{array}$ & $\begin{array}{l}\text { MRD within } 3 \text { months after } \\
\text { HSCT was independent factor } \\
\text { for CIR and LFS, not c-KIT } \\
\text { mutations }\end{array}$ & Wang et al. [50] \\
\hline $\begin{array}{l}\text { CML-C } \\
\quad \mathrm{P}\end{array}$ & $\begin{array}{l}\text { Nilotinib vs. } \\
\text { Imatinib }\end{array}$ & RCT & 13 & 267 & $\begin{array}{l}\text { MMR 12m: Nilotinib }(52.2) \% \text { vs. } \\
\text { Imatinib }(27.8 \%)(P<0.0001)\end{array}$ & $\begin{array}{l}\text { MMR at } 12 \text { months were } \\
\text { superior with nilotinib vs } \\
\text { imatinib in CML-CP } \\
\end{array}$ & Wang et al. [58] \\
\hline
\end{tabular}

a) APL, acute promyelocytic leukemia; RIF, Realgar-Indigo naturalis formula; ATRA, all-trans retinoic acid; RCT, randomized controlled trial; OS, overall survival rate; DFSAML, acute myeloid leukemia; HAA, homoharringtonine, cytarabine, aclarubicin; HAD, homoharringtonine, cytarabine, daunorubicin; DA, cytarabine, daunorubicin; EFS, event free survival; CIR, cumulative incidence of relapse; MRD, minimal residual disease; MMR, major molecular response; CML-CP, chronic myeloid leukemia in chronic phase; HID, haploidentical donor; ISD, HLA-identical sibling donor. 
relapse APL and finding new strategies for overcoming arsenic acid resistance [34]. Because ATO can hardly penetrate the blood-brain-barrier, the management of extra medullary relapse of APL in the central nervous system (CNS) was difficult. The Harbin group [35] first demonstrated that neuron cells were more tolerant to ATO than leukemia cells in vitro, based on these findings, the co-infusion of ATO and mannitol was introduced to patients with CNS relapse, as comparable arsenic levels were achieved in the cerebrospinal fluid and plasma, these patients exhibited improved outcomes, with a 5-year OS at $82.4 \%$ [36].

By incorporating modern molecular biotechnology into the discoveries of traditional Chinese medicine, fitting this unique system the international standards, Chinese doctors globally introduced a new era of therapeutic strategy for managing APL.

\section{Acute myeloid leukemia (AML) and acute lymphoblastic leukemia (ALL)}

To manage AML and ALL, Chinese doctors made the following innovative contributions: the identification of genetic abnormalities; novel regimens for chemotherapy or targeted therapy; and development of risk-stratificationdirected therapy.

The Shanghai group [37] and several other centers in China pioneered the genetic analysis of acute leukemia worldwide. Using exome sequencing, the mutations of DNA-methyltransferase 3A (DNMT3A) in acute monocytic leukemia were found to be correlated with the alterations of DNA methylation patterns and gene expression profiles. In cohorts of thousands of patients with newly diagnosed ALL, it was revealed that Chinese ALL patients demonstrated more adverse prognostic factors, such as breakpoint cluster region-Abelson (BCR-ABL), than western patients [38,39]. In AML, DNMT3A and mixed-lineage leukemia (MLL) mutations were associated with OS and DFS, whereas biallelic CCAAT/enhancer-binding protein alpha (CEBPA) or nucleophosmin1 (NPM1) mutations without DNMT3A mutations exhibited a better OS. Recently, using wholegenome sequencing, the Tianjin group [40,41] suggested that point mutations in SET domain containing 2 (SETD2) were associated with multiple major chromosomal aberrations, such as H3K36 trimethylation, and promoted the self-renewal potential of leukemia stem cells. In addition to genetic mutations, the series of aberrantly expressed microRNA and distinct metabolism signatures were indicated as prognostic markers for acute leukemia [42-44]. Not only did these cytogenetic and molecular abnormalities provide prognostic value, they also yielded insight into the mechanisms of leukemogenesis and contributed to the potential endeavors to find new therapeutic strategies.

Homoharringtonine, derived from a natural plant alkaloid, has been widely used in China to treat patients with
AML; however, its global impact has been limited as in the case of ATO. Recently, a multi-center, randomized, controlled trial in a large population from 17 institutions in China helped to solve this problem. Three induction regimens were assigned at a 1:1:1 ratio, which included HAA (homoharringtonine, cytarabine, aclarubicin), HAD (homoharringtonine, cytarabine, daunorubicin) and DA (cytarabine, daunorubicin). HAA was superior to DA, which was still the first-line treatment of induction therapy, with a superior CR rate of induction $(73 \%$ vs. $61 \%, P=0.0108)$ and 3 -year DFS (35.4\% vs. $23.1 \%, P=0.0023$ ) [45]. As a semisynthetic version of homoharringtonine, omacetaxinemepe succinate was recently approved by the Food and Drug Administration for the treatment of advanced leukemia; this unique agent with Chinese characters might play an increasing role in AML therapy and yield more influence on the guidelines dominated in the western world. Many candidate agents, such as oridonin, a diterpenoid extracted from medicinal herbs, targeting AML1-eight-twenty one oncoprotein (ETO) fusion protein and inhibiting the activity of c-Kit(+) leukemia-initiating cells in $\mathrm{t}(8 ; 21)$ AML, might be a potential lead compound for the molecular target-based therapy of leukemia $[46,47]$.

Although acute myeloid leukemia (AML) with $\mathrm{t}(8 ; 21)$ generally has a favorable prognosis, relapse occurs in $40 \%-60 \%$ of the patients, and the long-term survival is unsatisfactory [48]. Therefore, the early identification of patients with high-risk relapse in chemotherapy might provide valuable information regarding the selection of more aggressive strategies, such as allogeneic hematopoietic stem cell transplantation (allo-HSCT) as post remission therapy. It has been demonstrated in a multicenter trial in China that the minimal residual disease (MRD) status after the second consolidation, rather than induction or first consolidation, could discriminate high-risk relapse patients. Allo-HSCT could reduce the incidence of relapse and improve the survival rate compared with chemotherapy for these high-risk patients (cumulative incidence of relapse/CIR, HSCT vs. chemotherapy: $22.1 \%$ vs. $78.9 \%, P<0.0001)$. Therefore, MRD-directed pre-transplant risk stratification may improve the outcome of $t(8 ; 21)$ AML in CR1 [49]. Furthermore, for those high-risk patients who received allo-HSCT, MRD within 3 months after HSCT, rather than c-KIT mutations, was suggested as an independent factor for CIR and DFS in another multi-center study [50].

In sum, three aspects of the contributions by Chinese doctors could be integrated as "Prognostic genetic biomarkers-Regimens solutions-Risk-stratification-directed strategies," which are in accordance with the trends of "Precision Medicine" [51].

\section{Chronic myeloid leukemia (CML)}

Chinese patients with CML benefited from the introduction 
of tyrosine kinase inhibitors (TKIs) [52,53]. Because the innovations of new TKIs were monopolized by pharmaceutical industries in the western world, it is worth considering how to present "the voice from China" in this situation.

Allo-HSCT is no longer considered to be the first-line therapy for managing CML in the "TKI era" in developed countries. There is a shortage of evidence-based studies to address the optimization of therapeutic strategy for CML other than TKI. In prospective studies of China, imatinib results in comparable or better outcomes than an human leukocyte antigen (HLA)-identical sibling allo-HSCT as an initial therapy for CML-CP (chronic phase) [6], whereas allo-HSCT confers significant survival advantages for highand intermediate-risk patients with CML in AP (accelerated phase) or BC (blast crisis) compared with imatinib [7,54]. These studies helped to refine the European Leukemia Net guidelines for CML [55].

As BCR-ABL transcripts level play a critical role in guiding therapeutic strategies, it would be impossible to directly compare these results between different laboratories in the absence of uniform standards, not to mention initiating a multi-center study. Rather than using the log reduction method, the molecular response evaluated by BCR-ABL (IS) can better differentiate patients and allows for a comparison among molecular response results from different laboratories [56]. Through international cooperation, Peking University's laboratory was first certified by the BCR-ABL (IS) international laboratory and led the standardization of BCR-ABL monitoring in 23 central laboratories throughout China [57]. Based on uniform molecular monitoring, the "CML Consortium of China" was established and multicenter studies achieved promising results [58].

\section{Haploidentical hematopoietic stem cell trans- plantation (Haplo-HSCT)}

Allo-HSCT provides the powerful curative weapons for patients with the majority of hematological malignancies. Due to the "One Child Policy," there has been a shortage of HLA-identical siblings for Chinese patients who need HSCT, whereas only $11 \%$ could find matched unrelated donors in the total patients who tried to search for donors in "China Marrow Donor Program." Therefore, haplo-HSCT based on related family donors has a unique role in the treatment of hematologic diseases in China. Nevertheless, haplo-HSCT was once a dream because of the high incidence of rejection and severe graft-versus-host disease (GvHD) [59].

Based on series of mechanism research on cytokines induced immune tolerance [60-63], Peking University researchers developed a novel approach for HLA-mismatched/ haploidentical myeloablative blood and marrow transplantation without in vitro $\mathrm{T}$ cell depletion within the last 10 years (Beijing Protocol)[8,64]. Combinations of granulocyte col- ony-stimulating factor (G-CSF) and anti-thymocyte globulin (ATG) have been confirmed to play a key role in overcoming HLA barriers $[65,66]$, probably by immune regulatory cells, such as Th17/Tc 17, Treg, and myeloid-derived suppressor cells (MDSCs) [67-70]. In a prospective, randomized trial, it was suggested that $10 \mathrm{mg} \mathrm{kg}^{-1}$ ATG was superior to $6 \mathrm{mg} \mathrm{kg}^{-1}$ for lower grades III-IV acute GvHD [71].

In several single-center studies, haplo-HSCT was found to have similar therapeutic effects compared to HSCT with HLA identical sibling donor (ISD) [72] or matched unrelated donor (URD) [73], and may improve the outcomes of children compared with umbilical cord blood (UCB) transplantation [74]. Recently, in multi-center studies, haplo-HSCT exhibited a similar outcome as ISDs HSCT on adults with intermediate- or high-risk acute myeloid leukemia in CR1 [3]. Additionally, haplo-HSCT can achieve a desirable health-related quality of life (HRQoL) and a lower risk of late effects compared with ISD HSCT [75,76].

Haplo-HSCT is superior to chemotherapy as postremission treatment for intermediate- or high-risk AML or ALL in CR1. In a recent prospective study with intermediate- or high-risk AML, it was revealed that haplo-HSCT resulted in a lower cumulative incident of relapse $(12.0 \%$ vs. $57.8 \% ; P<0.0001)$ and superior 4 -year DFS $(73.1 \%$ vs. $44.2 \% ; P<0.0001)$ compared with the chemotherapy-alone group [77]. Similar results were observed among high- and stand-risk Ph-negative ALL CR1 patients after haploHSCT[4] [78].

As the new era in which "everyone has a donor" arrives [79], there will be a shift from donor shortage to diversification. HLA plays a predominant role in selection of the best donor in unrelated transplants, nevertheless, it has not been significantly correlated with transplant outcomes in haplo-HSCT [80,81]; therefore, we might focus on factors other than HLA to determine the impact on transplant outcomes. Based on a large sample size and relative consistency of transplant variables, the Beijing group [82] proposed an algorithm other than HLA for donor selection. It was suggested that choosing young, male, non-inherited maternal antigens(NIMA)-mismatched donors is reasonable. The transplants from older mothers and non-inherited paternal antigens (NIPA)-mismatched donors should probably be avoided. Additionally, donor-specific anti-HLA antibodies (DSAs) were indicated to be associated with primary graft failure (GF), transplant-related mortality and inferior overall survival following haplo-HSCT [83]. Donor selection based on other non-HLA systems, such as donor inhibitory killer cell immunoglobulin-like receptors (KIRs), remain to be further elucidated [84].

Since "Beijing Protocol" has been widely incorporated into clinical practice in most comprehensive HSCT centers of China, haplo-HSCT has become the largest donor source compared with ISD donors and take nearly $48 \%$ of total allo-HSCT cases in China (Figure 1). "Beijing Protocol" 


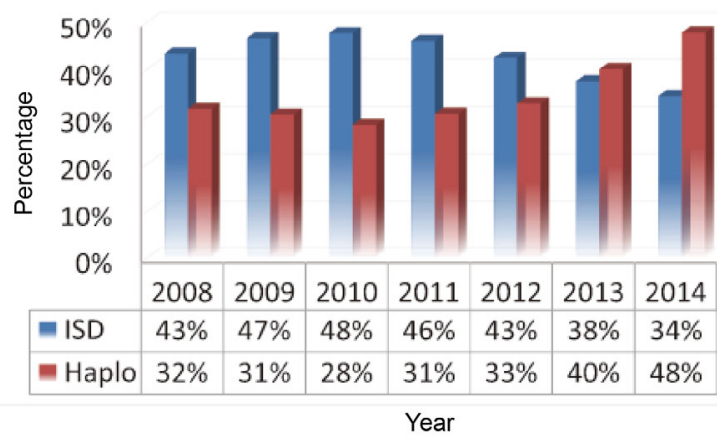

Figure 1 (color online) ISD vs. Haplo-HSCT in China (2008-2014). According to data collected by the Chinese HSCT registry group from 60 active centers of China between 2008 to 2014. Haploidentical donor become the largest donor source in China compared with ISD since 2013. The $Y$-axis represents the percentage of hematopoietic stem cell transplantation (HSCT) from human leukocyte antigen-identical sibling donor (ISD) or haploidentical donor (Haplo) in total allogeneic HSCT cases, the $X$-axis represents years.

was also replicated and conducted with promising results by Di Bartolomeo et al. [85] in Europe. As Handgretinger commented, "more than half of the HLA haplotype mismatched transplantations performed worldwide will follow similar protocols (Beijing Protocol) [86].

The development of Haplo-HSCT in China has changed the current situation of the international HSCT system. More innovative and standard clinical systems like "Beijing Protocol" are needed to keep the global impact of China.

\section{Conclusions and prospective}

As one of the most dynamic fields in translational medicine and precision medicine, there are both opportunities and challenges to anti-hematological malignancies. Only could deep mechanism studies, well designed clinical trials and multicenter collaborations bring the unique system of China to the world, which might be adopted into international systems or standards, and contribute to the global progression in fighting against hematologic malignancy.

The author(s) declare that they have no conflict of interest.

This work was supported by the National Natural Science Foundation of China (81230013, 81400146, 81530046) and the Beijing Municipal Science and Technology Program (Z141100000214011). The authors thank American Journal Experts (www.journalexperts.com) for the assistance in editing this manuscript.

1 Siegel RL, Miller KD, Jemal A. Cancer statistics, 2015. CA Cancer J Clin, 2015, 65: 5-29

2 Lv M, Huang XJ. Allogeneic hematopoietic stem cell transplantation in china: where we are and where to go. J Hematol Oncol, 2012, 5: 10

3 Wang Y, Liu QF, Xu LP, Liu KY, Zhang XH, Ma X, Fan ZP, Wu DP, Huang XJ. Haploidentical vs identical-sibling transplant for aml in remission: a multicenter, prospective study. Blood, 2015, 125: 3956-3962

4 Yan CH, Jiang Q, Wang J, Xu LP, Liu DH, Jiang H, Chen H, Zhang XH, Liu KY, Huang XJ. Superior survival of unmanipulated haploidentical hematopoietic stem cell transplantation compared with chemotherapy alone used as post-remission therapy in adults with standard-risk acute lymphoblastic leukemia in first complete remission. Biol Blood Marrow Transplant, 2014, 20: 1314-1321

5 Zhu HH, Wu DP, Jin J, Li JY, Ma J, Wang JX, Jiang H, Chen SJ, Huang XJ. Oral tetra-arsenic tetra-sulfide formula versus intravenous arsenic trioxide as first-line treatment of acute promyelocytic leukemia: a multicenter randomized controlled trial. J Clin Oncol, 2013, 31: 4215-4221

6 Jiang Q, Xu LP, Liu DH, Liu KY, Gale RP, Zhang MJ, Jiang B, Zhang XH, Wang Y, Chen SS, Zhao XY, Chen H, Jiang H, Chen YH, Han W, Qin YZ, Liu YR, Lai YY, Lv M, Huang XJ. Imatinib results in better outcomes than HLA-identical sibling transplants in young persons with newly diagnosed chronic-phase chronic myelogenous leukemia. Leukemia, 2013, 27: 2410-2413

7 Jiang Q, Xu LP, Liu DH, Liu KY, Chen SS, Jiang B, Jiang H, Chen H, Chen YH, Han W, Zhang XH, Wang Y, Qin YZ, Liu YR, Lai YY, Huang XJ. Imatinib mesylate versus allogeneic hematopoietic stem cell transplantation for patients with chronic myelogenous leukemia in the accelerated phase. Blood, 2011, 117: 3032-3040

8 Wang Y, Liu DH, Liu KY, Xu LP, Zhang XH, Han W, Chen H, Chen YH, Wang FR, Wang JZ, Sun YQ, Huang XJ. Long-term follow-up of haploidentical hematopoietic stem cell transplantation without in vitro $\mathrm{T}$ cell depletion for the treatment of leukemia: nine years of experience at a single center. Cancer, 2013, 119: 978-985

9 Bernard J, Weil M, Boiron M, Jacquillat C, Flandrin G, Gemon MF. Acute promyelocytic leukemia: results of treatment by daunorubicin. Blood, 1973, 41: 489-496

10 Ventura GJ, Hester JP, Dixon DO, Khorana S, Keating MJ. Analysis of risk factors for fatal hemorrhage during induction therapy of patients with acute promyelocytic leukemia. Hematol Pathol, 1989, 3: 23-28

11 Coombs CC, Tavakkoli M, Tallman MS. Acute promyelocytic leukemia: where did we start, where are we now, and the future. Blood Cancer J, 2015, 5: e304

12 Rao Y, Li R, Zhang D. A drug from poison: how the therapeutic effect of arsenic trioxide on acute promyelocytic leukemia was discovered. Sci China Life Sci, 2013, 56: 495-502

13 Huang ME, Ye YC, Chen SR, Zhao JC, Gu LJ, Cai JR, Zhao L, Xie JX, Shen ZX, Wang ZY. All-trans retinoic acid with or without low dose cytosine arabinoside in acute promyelocytic leukemia. Report of 6 cases. Chin Med J, 1987, 100: 949-953

14 Huang ME, Ye YC, Chen SR, Chai JR, Lu JX, Zhoa L, Gu LJ, Wang $\mathrm{ZY}$. Use of all-trans retinoic acid in the treatment of acute promyelocytic leukemia. Blood, 1988, 72: 567-572

15 Tallman MS, Andersen JW, Schiffer CA, Appelbaum FR, Feusner JH, Ogden A, Shepherd L, Willman C, Bloomfield CD, Rowe JM, Wiernik PH. All-trans-retinoic acid in acute promyelocytic leukemia. N Engl J Med, 1997, 337: 1021-1028

16 Castaigne S, Chomienne C, Daniel MT, Ballerini P, Berger R, Fenaux P, Degos L. All-trans retinoic acid as a differentiation therapy for acute promyelocytic leukemia. I. Clinical results. Blood, 1990, 76: 1704-1709

17 Wang ZY, Chen Z. Acute promyelocytic leukemia: from highly fatal to highly curable. Blood, 2008, 111: 2505-2515

18 Zhang TD, Chen GQ, Wang ZG, Wang ZY, Chen SJ, Chen Z. Arsenic trioxide, a therapeutic agent for APL. Oncogene, 2001, 20: 7146-7153

19 Lu DP, Qiu JY, Jiang B, Wang Q, Liu KY, Liu YR, Chen SS. Tetra-arsenic tetra-sulfide for the treatment of acute promyelocytic leukemia: a pilot report. Blood, 2002, 99: 3136-3143

20 Shen ZX, Shi ZZ, Fang J, Gu BW, Li JM, Zhu YM, Shi JY, Zheng PZ, Yan H, Liu YF, Chen Y, Shen Y, Wu W, Tang W, Waxman S, De The H, Wang ZY, Chen SJ, Chen Z. All-trans retinoic ac$\mathrm{id} / \mathrm{As} 2 \mathrm{O} 3$ combination yields a high quality remission and survival in 
newly diagnosed acute promyelocytic leukemia. Proc Natl Acad Sci USA, 2004, 101: 5328-5335

21 Chen GQ, Zhu J, Shi XG, Ni JH, Zhong HJ, Si GY, Jin XL, Tang W, Li XS, Xong SM, Shen ZX, Sun GL, Ma J, Zhang P, Zhang TD, Gazin C, Naoe T, Chen SJ, Wang ZY, Chen Z. In vitro studies on cellular and molecular mechanisms of arsenic trioxide (As2O3) in the treatment of acute promyelocytic leukemia: As2O3 induces NB4 cell apoptosis with downregulation of Bcl-2 expression and modulation of PML-RAR alpha/PML proteins. Blood, 1996, 88: 1052-1061

22 Chen GQ, Shi XG, Tang W, Xiong SM, Zhu J, Cai X, Han ZG, Ni JH, Shi GY, Jia PM, Liu MM, He KL, Niu C, Ma J, Zhang P, Zhang TD, Paul P, Naoe T, Kitamura K, Miller W, Waxman S, Wang ZY, de The H, Chen SJ, Chen Z. Use of arsenic trioxide (As2O3) in the treatment of acute promyelocytic leukemia (APL): I. As2O3 exerts dose-dependent dual effects on APL cells. Blood, 1997, 89: 3345-3353

23 Shen ZX, Chen GQ, Ni JH, Li XS, Xiong SM, Qiu QY, Zhu J, Tang W, Sun GL, Yang KQ, Chen Y, Zhou L, Fang ZW, Wang YT, Ma J, Zhang P, Zhang TD, Chen SJ, Chen Z, Wang ZY. Use of arsenic trioxide (As2O3) in the treatment of acute promyelocytic leukemia (APL): Ii. Clinical efficacy and pharmacokinetics in relapsed patients. Blood, 1997, 89: 3354-3360

24 Meng R, Zhou J, Sui M, Li Z, Feng G, Yang B. Arsenic trioxide promotes mitochondrial DNA mutation and cell apoptosis in primary APL cells and NB4 cell line. Sci China Life Sci, 2010, 53: 87-93

25 Raffoux E, Rousselot P, Poupon J, Daniel MT, Cassinat B, Delarue R, Taksin AL, Rea D, Buzyn A, Tibi A, Lebbe G, Cimerman P, Chomienne C, Fermand JP, de The H, Degos L, Hermine O, Dombret $\mathrm{H}$. Combined treatment with arsenic trioxide and all-trans-retinoic acid in patients with relapsed acute promyelocytic leukemia. J Clin Oncol, 2003, 21: 2326-2334

26 Estey E, Garcia-Manero G, Ferrajoli A, Faderl S, Verstovsek S, Jones $\mathrm{D}$, Kantarjian H. Use of all-trans retinoic acid plus arsenic trioxide as an alternative to chemotherapy in untreated acute promyelocytic leukemia. Blood, 2006, 107: 3469-3473

27 Sanz MA, Grimwade D, Tallman MS, Lowenberg B, Fenaux P, Estey EH, Naoe T, Lengfelder E, Buchner T, Dohner H, Burnett AK, Lo-Coco F. Management of acute promyelocytic leukemia: recommendations from an expert panel on behalf of the european leukemianet. Blood, 2009, 113: 1875-1891

28 Lo-Coco F, Avvisati G, Vignetti M, Thiede C, Orlando SM, Iacobelli S, Ferrara F, Fazi P, Cicconi L, Di Bona E, Specchia G, Sica S, Divona M, Levis A, Fiedler W, Cerqui E, Breccia M, Fioritoni G, Salih HR, Cazzola M, Melillo L, Carella AM, Brandts CH, Morra E, von Lilienfeld-Toal M, Hertenstein B, Wattad M, Lubbert M, Hanel M, Schmitz N, Link H, Kropp MG, Rambaldi A, La Nasa G, Luppi M, Ciceri F, Finizio O, Venditti A, Fabbiano F, Dohner K, Sauer M, Ganser A, Amadori S, Mandelli F, Dohner H, Ehninger G, Schlenk RF, Platzbecker U, Gruppo Italiano Malattie Ematologiche dA, German-Austrian Acute Myeloid Leukemia Study G, Study Alliance L. Retinoic acid and arsenic trioxide for acute promyelocytic leukemia. N Engl J Med, 2013, 369: 111-121

29 Huang SL. Clinical study on the treatment of acute promyelocytic leukemia with composite indigo naturalis tablets. Zhonghua Xue Ye Xue Za Zhi, 1995, 16: 26-28

30 Wang L, Zhou GB, Liu P, Song JH, Liang Y, Yan XJ, Xu F, Wang BS, Mao JH, Shen ZX, Chen SJ, Chen Z. Dissection of mechanisms of chinese medicinal formula realgar-indigo naturalis as an effective treatment for promyelocytic leukemia. Proc Natl Acad Sci USA, 2008, 105: 4826-4831

31 Zhu HH, Huang XJ. Oral arsenic and retinoic acid for non-high-risk acute promyelocytic leukemia. N Engl J Med, 2014, 371: 2239-2241

32 Zeidan AM, Gore SD. New strategies in acute promyelocytic leukemia: moving to an entirely oral, chemotherapy-free upfront management approach. Clin Cancer Res, 2014, 20: 4985-4993

33 Goto E, Tomita A, Hayakawa F, Atsumi A, Kiyoi H, Naoe T. Missense mutations in PML-RARA are critical for the lack of responsiveness to arsenic trioxide treatment. Blood, 2011, 118: 1600-1609

34 Zhu HH, Qin YZ, Huang XJ. Resistance to arsenic therapy in acute promyelocytic leukemia. N Engl J Med, 2014, 370: 1864-1866

35 Zhou J, Meng R, Sui X, Li W, Yang B. Various tolerances to arsenic trioxide between human cortical neurons and leukemic cells. Sci China Ser C: Life Sci, 2006, 49: 567-572

36 Wang H, Cao F, Li J, Li L, Li Y, Shi C, Lan W, Li D, Zhao H, Zhang Y, Zhang Z, Liu X, Meng R, Yang B, Zhou J. Arsenic trioxide and mannitol for the treatment of acute promyelocytic leukemia relapse in the central nervous system. Blood, 2014, 124: 1998-2000

37 Yan XJ, Xu J, Gu ZH, Pan CM, Lu G, Shen Y, Shi JY, Zhu YM, Tang L, Zhang XW, Liang WX, Mi JQ, Song HD, Li KQ, Chen Z, Chen SJ. Exome sequencing identifies somatic mutations of DNA methyltransferase gene DNMT3A in acute monocytic leukemia. Nat Genet, 2011, 43: 309-315

38 Chen B, Wang YY, Shen Y, Zhang WN, He HY, Zhu YM, Chen HM, Gu CH, Fan X, Chen JM, Cao Q, Yang G, Jiang CL, Weng XQ, Zhang XX, Xiong SM, Shen ZX, Jiang H, Gu LJ, Chen Z, Mi JQ, Chen SJ. Newly diagnosed acute lymphoblastic leukemia in China (i): abnormal genetic patterns in 1346 childhood and adult cases and their comparison with the reports from western countries. Leukemia, 2012, 26: 1608-1616

39 Mi JQ, Wang X, Yao Y, Lu HJ, Jiang XX, Zhou JF, Wang JH, Jiao B, Shen SH, Tang JY, Gu LJ, Jiang H, Ma LY, Hao SG, Chen FY, Xiong SM, Shen ZX, Chen Z, Chen B, Chen SJ. Newly diagnosed acute lymphoblastic leukemia in China (ii): prognosis related to genetic abnormalities in a series of 1091 cases. Leukemia, 2012, 26: $1507-1516$

40 Zhu X, He F, Zeng H, Ling S, Chen A, Wang Y, Yan X, Wei W, Pang Y, Cheng H, Hua C, Zhang Y, Yang X, Lu X, Cao L, Hao L, Dong L, Zou W, Wu J, Li X, Zheng S, Yan J, Zhou J, Zhang L, Mi S, Wang X, Zhang L, Zou Y, Chen Y, Geng Z, Wang J, Zhou J, Liu X, Wang J, Yuan W, Huang G, Cheng T, Wang QF. Identification of functional cooperative mutations of SETD2 in human acute leukemia. Nat Genet, 2014, 46: 287-293

41 Wang Q, Cheng T. Evidences for mutations in the histone modifying gene SETD2 as critical drivers in leukemia development. Sci China Life Sci, 2014, 57: 944-946

42 Lv M, Zhang X, Jia H, Li D, Zhang B, Zhang H, Hong M, Jiang T, Jiang Q, Lu J, Huang X, Huang B. An oncogenic role of miR-142-3p in human T-cell acute lymphoblastic leukemia (T-ALL) by targeting glucocorticoid receptor-alpha and cAMP/PKA pathways. Leukemia, 2012, 26: 769-777

43 Li Y, Gao L, Luo X, Wang L, Gao X, Wang W, Sun J, Dou L, Li J, Xu C, Wang L, Zhou M, Jiang M, Zhou J, Caligiuri MA, Nervi C, Bloomfield CD, Marcucci G, Yu L. Epigenetic silencing of microRNA-193a contributes to leukemogenesis in $\mathrm{t}(8 ; 21)$ acute myeloid leukemia by activating the PTEN/PI3K signal pathway. Blood, 2013, 121: 499-509

44 Chen WL, Wang JH, Zhao AH, Xu X, Wang YH, Chen TL, Li JM, Mi JQ, Zhu YM, Liu YF, Wang YY, Jin J, Huang H, Wu DP, Li Y, Yan XJ, Yan JS, Li JY, Wang S, Huang XJ, Wang BS, Chen Z, Chen SJ, Jia W. A distinct glucose metabolism signature of acute myeloid leukemia with prognostic value. Blood, 2014, 124: 1645-1654

45 Jin J, Wang JX, Chen FF, Wu DP, Hu J, Zhou JF, Hu JD, Wang JM, Li JY, Huang XJ, Ma J, Ji CY, Xu XP, Yu K, Ren HY, Zhou YH, Tong Y, Lou YJ, Ni WM, Tong HY, Wang HF, Mi YC, Du X, Chen BA, Shen Y, Chen Z, Chen SJ. Homoharringtonine-based induction regimens for patients with de-novo acute myeloid leukaemia: a multicentre, open-label, randomised, controlled phase 3 trial. Lancet Oncol, 2013, 14: 599-608

46 Zhen T, Wu CF, Liu P, Wu HY, Zhou GB, Lu Y, Liu JX, Liang Y, Li KK, Wang YY, Xie YY, He MM, Cao HM, Zhang WN, Chen LM, Petrie K, Chen SJ, Chen Z. Targeting of AML1-ETO in $\mathrm{t}(8 ; 21)$ leukemia by oridonin generates a tumor suppressor-like protein. Sci Transl Med, 2012, 4: 127ra138

47 Zhou GB, Kang H, Wang L, Gao L, Liu P, Xie J, Zhang FX, Weng XQ, Shen ZX, Chen J, Gu LJ, Yan M, Zhang DE, Chen SJ, Wang ZY, Chen Z. Oridonin, a diterpenoid extracted from medicinal herbs, targets AML1-ETO fusion protein and shows potent antitumor activity with low adverse effects on $\mathrm{t}(8 ; 21)$ leukemia in vitro and in vivo. 
Blood, 2007, 109: 3441-3450

48 Marcucci G, Mrozek K, Ruppert AS, Maharry K, Kolitz JE, Moore JO, Mayer RJ, Pettenati MJ, Powell BL, Edwards CG, Sterling LJ, Vardiman JW, Schiffer CA, Carroll AJ, Larson RA, Bloomfield CD. Prognostic factors and outcome of core binding factor acute myeloid leukemia patients with $\mathrm{t}(8 ; 21)$ differ from those of patients with inv(16): a cancer and leukemia group B study. J Clin Oncol, 2005, 23: 5705-5717

49 Zhu HH, Zhang XH, Qin YZ, Liu DH, Jiang H, Chen H, Jiang Q, Xu LP, Lu J, Han W, Bao L, Wang Y, Chen YH, Wang JZ, Wang FR, Lai YY, Chai JY, Wang LR, Liu YR, Liu KY, Jiang B, Huang XJ. MRD-directed risk stratification treatment may improve outcomes of $\mathrm{t}(8 ; 21)$ AML in the first complete remission: results from the AML05 multicenter trial. Blood, 2013, 121: 4056-4062

50 Wang Y, Wu DP, Liu QF, Qin YZ, Wang JB, Xu LP, Liu YR, Zhu $\mathrm{HH}$, Chen J, Dai M, Huang XJ. In adults with $\mathrm{t}(8 ; 21) \mathrm{AML}$, posttransplant RUNX1/RUNX1T1-based MRD monitoring, rather than c-KIT mutations, allows further risk stratification. Blood, 2014, 124: $1880-1886$

51 Jameson JL, Longo DL. Precision medicine-personalized, problematic, and promising. N Engl J Med, 2015, 372: 2229-2234

52 Wang AH, Wang YY, Yao Y, Xu ZZ, Zhou L, Wang L, Zhang L, Chen Y, Shen ZX, Hu J, Li JM. Summary of 615 patients of chronic myeloid leukemia in shanghai from 2001 to 2006. J Exp Clin Cancer Res, 2010, 29: 20

53 Jiang H, Chen SS, Jiang B, Jiang Q, Qin YZ, Lai YY, Huang XJ. Seven-year response to imatinib as initial treatment versus retreatment in chinese patients with chronic myelogenous leukemia in the chronic phase. Ann Hematol, 2011, 90: 41-46

54 Jiang H, Xu LP, Liu DH, Liu KY, Chen SS, Jiang B, Jiang Q, Chen H, Chen YH, Han W, Zhang XH, Wang Y, Wang JZ, Wang FR, Qin YZ, Lai YY, Huang XJ. Allogeneic hematopoietic SCT in combination with tyrosine kinase inhibitor treatment compared with TKI treatment alone in $\mathrm{cml}$ blast crisis. Bone Marrow Transplant, 2014, 49: 1146-1154

55 Baccarani M, Deininger MW, Rosti G, Hochhaus A, Soverini S, Apperley JF, Cervantes F, Clark RE, Cortes JE, Guilhot F, Hjorth-Hansen H, Hughes TP, Kantarjian HM, Kim DW, Larson RA, Lipton JH, Mahon FX, Martinelli G, Mayer J, Muller MC, Niederwieser D, Pane F, Radich JP, Rousselot P, Saglio G, Saussele S, Schiffer C, Silver R, Simonsson B, Steegmann JL, Goldman JM, Hehlmann R. European leukemianet recommendations for the management of chronic myeloid leukemia: 2013. Blood, 2013, 122: 872-884

56 Branford S, Fletcher L, Cross NC, Muller MC, Hochhaus A, Kim DW, Radich JP, Saglio G, Pane F, Kamel-Reid S, Wang YL, Press RD, Lynch K, Rudzki Z, Goldman JM, Hughes T. Desirable performance characteristics for BCR-ABL measurement on an international reporting scale to allow consistent interpretation of individual patient response and comparison of response rates between clinical trials. Blood, 2008, 112: 3330-3338

57 Qin YZ, Jiang Q, Jiang H, Li JL, Li LD, Zhu HH, Lai YY, Lu XJ, Liu YR, Jiang B, Huang XJ. Which method better evaluates the molecular response in newly diagnosed chronic phase chronic myeloid leukemia patients with imatinib treatment, BCR-ABL(IS) or log reduction from the baseline level? Leuk Res, 2013, 37: 1035-1040

58 Wang J, Shen ZX, Saglio G, Jin J, Huang H, Hu Y, Du X, Li J, Meng F, Zhu H, Hu J, Wang J, Hou M, Hertle S, Menssen HD, Ortmann CE, Tribouley C, Yuan Y, Baccarani M, Huang X. Phase 3 study of nilotinib vs imatinib in chinese patients with newly diagnosed chronic myeloid leukemia in chronic phase: ENESTChina. Blood, 2015, 125: $2771-2778$

59 Szydlo R, Goldman JM, Klein JP, Gale RP, Ash RC, Bach FH, Bradley BA, Casper JT, Flomenberg N, Gajewski JL, Gluckman E, Henslee-Downey PJ, Hows JM, Jacobsen N, Kolb HJ, Lowenberg B, Masaoka T, Rowlings PA, Sondel PM, van Bekkum DW, van Rood JJ, Vowels MR, Zhang MJ, Horowitz MM. Results of allogeneic bone marrow transplants for leukemia using donors other than HLA-identical siblings. J Clin Oncol, 1997, 15: 1767-1777
60 Chen SH, Li X, Huang XJ. Effect of recombinant human granulocyte colony-stimulating factor on T-lymphocyte function and the mechanism of this effect. Int J Hematol, 2004, 79: 178-184

61 Huang XJ, Chen YH, Xu LP, Zhang YC, Liu DH, Guo NL, Lu DP. Combined transplantation of G-CSF primed allogeneic bone marrow cells and peripheral blood stem cells in treatment of severe aplastic anemia. Chin Med J (Engl), 2004, 117: 604-607

62 Jun HX, Jun CY, Yu ZX. In vivo induction of T-cell hyporesponsiveness and alteration of immunological cells of bone marrow grafts using granulocyte colony-stimulating factor. Haematologica, 2004, 89: $1517-1524$

63 Jun HX, Jun CY, Yu ZX. A direct comparison of immunological characteristics of granulocyte colony-stimulating factor (G-CSF)primed bone marrow grafts and G-CSF-mobilized peripheral blood grafts. Haematologica, 2005, 90: 715-716

64 Huang XJ, Liu DH, Liu KY, Xu LP, Chen H, Han W, Chen YH, Wang JZ, Gao ZY, Zhang YC, Jiang Q, Shi HX, Lu DP. Haploidentical hematopoietic stem cell transplantation without in vitro T-cell depletion for the treatment of hematological malignancies. Bone Marrow Transplant, 2006, 38: 291-297

65 Chang YJ, Huang XJ. Use of G-CSF-stimulated marrow in allogeneic hematopoietic stem cell transplantation settings: a comprehensive review. Clin Transplant, 2011, 25: 13-23

66 Chang YJ, Huang XJ. Haploidentical SCT: the mechanisms underlying the crossing of HLA barriers. Bone Marrow Transplant, 2014, 49: 873-879

67 Zhao XY, Lv M, Xu LL, Qian X, Huang XJ. Donor Th17 cells and IL-21 may contribute to the development of chronic graft-versus-host disease after allogeneic transplantation. Eur J Immunol, 2013, 43: $838-850$

68 Zhao XY, Xu LL, Lu SY, Huang XJ. Il-17-producing T cells contribute to acute graft-versus-host disease in patients undergoing unmanipulated blood and marrow transplantation. Eur J Immunol, 2011, 41: 514-526

69 Lv M, Zhao XS, Hu Y, Chang YJ, Zhao XY, Kong Y, Zhang XH, Xu LP, Liu KY, Huang XJ. Monocytic and promyelocytic myeloid-derived suppressor cells may contribute to G-CSF-induced immune tolerance in haplo-identical allogeneic hematopoietic stem cell transplantation. Am J Hematol, 2015, 90: E9-E16

70 Lu SY, Liu KY, Liu DH, Xu LP, Huang XJ. High frequencies of $\mathrm{CD}_{2} \mathrm{~L}^{+}$naive regulatory $\mathrm{T}$ cells in allografts are associated with a low risk of acute graft-versus-host disease following unmanipulated allogeneic haematopoietic stem cell transplantation. Clin Exp Immunol, 2011, 165: 264-277

71 Wang Y, Fu HX, Liu DH, Xu LP, Zhang XH, Chang YJ, Chen YH, Wang FR, Sun YQ, Tang FF, Liu KY, Huang XJ. Influence of two different doses of antithymocyte globulin in patients with standard-risk disease following haploidentical transplantation: a randomized trial. Bone Marrow Transplant, 2014, 49: 426-433

72 Lu DP, Dong L, Wu T, Huang XJ, Zhang MJ, Han W, Chen H, Liu DH, Gao ZY, Chen YH, Xu LP, Zhang YC, Ren HY, Li D, Liu KY. Conditioning including antithymocyte globulin followed by unmanipulated HLA-mismatched/haploidentical blood and marrow transplantation can achieve comparable outcomes with HLA-identical sibling transplantation. Blood, 2006, 107: 3065-3073

73 Huang XJ, Xu LP, Liu KY, Liu DH, Wang Y, Chen H, Chen YH, Han W, Wang JZ, Chen Y, Zhang XH, Shi HX, Wang FR, Tang FF. Partially matched related donor transplantation can achieve outcomes comparable with unrelated donor transplantation for patients with hematologic malignancies. Clin Cancer Res, 2009, 15: 4777-4783

74 Mo XD, Zhao XY, Liu DH, Chen YH, Xu LP, Zhang XH, Chen H, Han W, Wang Y, Wang FR, Wang JZ, Liu KY, Huang XJ. Umbilical cord blood transplantation and unmanipulated haploidentical hematopoietic SCT for pediatric hematologic malignances. Bone Marrow Transplant, 2014, 49: 1070-1075

75 Mo XD, Xu LP, Liu DH, Chen YH, Han W, Zhang XH, Chen H, Wang Y, Wang JZ, Liu KY, Huang XJ. Patients receiving HLA-haploidentical/partially matched related allo-HSCT can achieve desirable health-related QoL that is comparable to that of patients receiving HLA-identical sibling allo-HSCT. Bone Marrow Transplant, 
2012, 47: 1201-1205

76 Mo XD, Xu LP, Liu DH, Zhang XH, Chen H, Chen YH, Han W, Wang Y, Wang FR, Wang JZ, Liu KY, Huang XJ. Nonmalignant late effects in survivors of partially matched donor hematopoietic stem cell transplantation. Biol Blood Marrow Transplant, 2013, 19: 777-783

77 Huang XJ, Zhu HH, Chang YJ, Xu LP, Liu DH, Zhang XH, Jiang B, Jiang Q, Jiang H, Chen YH, Chen H, Han W, Liu KY, Wang Y. The superiority of haploidentical related stem cell transplantation over chemotherapy alone as postremission treatment for patients with intermediate- or high-risk acute myeloid leukemia in first complete remission. Blood, 2012, 119: 5584-5590

78 Sun YQ, Wang J, Jiang Q, Xu LP, Liu DH, Zhang XH, Liu KY, Huang XJ. Haploidentical hematopoietic SCT may be superior to conventional consolidation/maintenance chemotherapy as post-remission therapy for high-risk adult all. Bone Marrow Transplant, 2015, 50: 20-25

79 Champlin R. Now everyone has a donor for HSCT. Blood, 2011, 118: 218

80 Wang M, Dong YJ, Qiu ZX, Wang MJ, Liu W, Wang LH, Li Y, Sun YH, Xu WL, Ou JP, Wang WS, Liang ZY, Wang Q, Cen XN, Ren HY. HLA disparity is not crucial for the survival rate and severity of chronic health conditions in adult recipients following family donor hematopoietic stem cell transplantation. Int J Hematol, 2015, 101: $75-82$

81 Huo MR, Xu LP, Li D, Liu DH, Liu KY, Chen H, Han W, Chen YH,
Wang Y, Wang JZ, Zhang XH, Zhao XY, Huang XJ. The effect of hla disparity on clinical outcome after HLA-haploidentical blood and marrow transplantation. Clin Transplant, 2012, 26: 284-291

82 Wang Y, Chang YJ, Xu LP, Liu KY, Liu DH, Zhang XH, Chen H, Han W, Chen YH, Wang FR, Wang JZ, Chen Y, Yan CH, Huo MR, Li D, Huang XJ. Who is the best donor for a related HLA haplotype-mismatched transplant? Blood, 2014, 124: 843-850

83 Chang YJ, Zhao XY, Xu LP, Zhang XH, Wang Y, Han W, Chen H, Wang FR, Mo XD, Zhang YY, Huo MR, Zhao XS, Y K, Liu KY, Huang XJ. Donor-specific anti-human leukocyte antigen antibodies were associated with primary graft failure after unmanipulated haploidentical blood and marrow transplantation: a prospective study with randomly assigned training and validation sets. J Hematol Oncol, 2015, 8: 84

84 Zhao XY, Chang YJ, Zhao XS, Xu LP, Zhang XH, Liu KY, Li D, Huang XJ. Recipient expression of ligands for donor inhibitory kirs enhances NK-cell function to control leukemic relapse after haploidentical transplantation. Eur J Immunol, 2015, 45: 2396-2408

85 Di Bartolomeo P, Santarone S, De Angelis G, Picardi A, Cudillo L, Cerretti R, Adorno G, Angelini S, Andreani M, De Felice L, Rapanotti MC, Sarmati L, Bavaro P, Papalinetti G, Di Nicola M, Papola F, Montanari M, Nagler A, Arcese W. Haploidentical, unmanipulated, G-CSF-primed bone marrow transplantation for patients with high-risk hematologic malignancies. Blood, 2013, 121: 849-857

86 Handgretinger R. Haploidentical transplantation: the search for the best donor. Blood, 2014, 124: 827-828

Open Access This article is distributed under the terms of the Creative Commons Attribution License which permits any use, distribution, and reproduction in any medium, provided the original author(s) and source are credited. 